\title{
Ryszard Węgrzyn
}

Cracow University of Economics

e-mail: wegrzynr@uek.krakow.pl

ORCID: 0000-0001-6055-6041

\section{EFFECTIVENESS OF DYNAMIC HEDGING USING OPTIONS ON THE WIG20 IN CURRENT MARKET CONDITIONS*}

SKUTECZNOŚĆ HEDGINGU DYNAMICZNEGO Z ZASTOSOWANIEM OPCJI NA WIG20 W AKTUALNYCH WARUNKACH RYNKOWYCH

DOI: $10.15611 / \mathrm{pn} .2020 .2 .09$

JEL Classification: G11

\begin{abstract}
Summary: Based on previous research on the deviations of the prices of options on the WIG20 from the arbitrage restrictions and features, it was found that the number and scale of these deviations clearly decreased, thus improving the quality of the arbitrage pricing of options. The purpose of this work in this context is to determine the effectiveness of dynamic hedging using options on the WIG20 in current market conditions and to compare the results with the results of previously conducted research. The study was carried out using the historical scenario method based on data from 2017-2018 shared by the Warsaw Stock Exchange. To compare the effectiveness of dynamic hedging, Value at Risk was applied to the unhedged portfolio and portfolios hedged by a specific hedging method. Based on the research, it can be concluded that among the delta, delta-gamma and delta-gamma-vega hedging analyzed, the most effective solution in the current market conditions is delta hedging. The research results indicate that despite qualitative changes on the market that improve the option price relations the delta-gamma and delta-gamma-vega hedging are in practice worse solutions than delta hedging.
\end{abstract}

Keywords: option, hedging, delta, gamma, vega.

Streszczenie: Na podstawie przeprowadzonych wcześniej badań odchyleń cen opcji na WIG20 od określonych ograniczeń i właściwości arbitrażowych stwierdzono, że liczebność i skala tych odchyleń wyraźnie się zmniejszyły, poprawiając jakość arbitrażowej wyceny opcji. Cele artykułu to określenie skuteczności hedgingu dynamicznego z zastosowaniem opcji na WIG20 w aktualnych warunkach rynkowych i porównanie uzyskanych wyników

* The article was financed from funds allocated to the Faculty of Management of the University of Economics in Krakow as part of a grant for maintaining research potential. 
z wynikami przeprowadzonych wcześniej analiz. Badanie przeprowadzono metodą scenariusza historycznego na podstawie danych z lat 2017-2018 udostępnionych przez GPW w Warszawie. Do porównania skuteczności hedgingu dynamicznego zastosowano oszacowaną wartość zagrożoną (VaR) dla portfeli niezabezpieczonych i zabezpieczonych określonymi metodami hedgingu. Stwierdzono, że wśród przeanalizowanych hedgingów delta, deltagamma i delta-gamma-vega najskuteczniejszym rozwiązaniem w obecnych warunkach rynkowych jest hedging delta. Mimo zmian jakościowych na rynku poprawiających relacje cenowe opcji hedgingi delta-gamma i delta-gamma-vega są w praktyce gorszymi rozwiązaniami niż hedging delta.

Slowa kluczowe: opcja, hedging, delta, gamma, vega.

\section{Introduction}

Dynamic hedging using options consists in constructing a portfolio composed of options and an underlying instrument, so that changes in the prices of underlying instruments were compensated by changes in the option prices, which means that the portfolio is hedged against current changes in its value. The previously conducted research on the development of the Polish options market highlighted the changes in the deviations of option prices from certain relations resulting from arbitrage. Based on the results obtained, it was found that the number and scale of these deviations clearly decreased, improving the quality of the arbitrage pricing of options [Węgrzyn $2010 ; 2011]$. In this context, it is worth assessing the effectiveness of dynamic hedging in current market conditions.

The purpose of this work is to determine the effectiveness of dynamic hedging using options on the WIG20 and to compare the results with the results of previously conducted research, in particular to assessing the effectiveness of delta hedging and delta-gamma-vega hedging.

The basic research hypothesis concerned the differences in the effectiveness of individual dynamic hedging methods and assumed the highest effectiveness of deltagamma-vega hedging and the lowest effectiveness of delta hedging. The verification of this hypothesis was made by comparing the analyzed scenarios of hedging the portfolio in the same market conditions. To compare the effectiveness of hedging, among others Value at Risk was used for unhedged and hedged portfolios by a specific method. A detailed analysis was made of portfolios consisting of shares included in the WIG20 index and selected European call options on the WIG20 index, traded on the Warsaw Stock Exchange. The data provided by the stock exchange for the period 2017-2018 regarding options, the WIG20 index as well as the estimated Greek coefficients of the respective options were used for the analysis. The results obtained for this research period were compared with the results of similar analyzes for the period from July 2007 to January 2008. 


\section{Dynamic hedging}

Hedging with the use of options can be divided into static hedging - consisting in constructing a hedged portfolio and keeping it until the option expiry date, and dynamic hedging - consisting in constructing a hedged portfolio and its further regular reconstruction (balancing) during the hedging period. Greek coefficients (also 'Greeks') were used for the proper construction of the portfolio [Spremann 1991; Jarrow, Turnbull 2000; Chance 2004; Weron, Weron 2005]. The most important Greeks in the context of hedging the portfolio include delta, gamma and vega, because they concern the main risk factors of such a portfolio - the price of the underlying instrument and its volatility. Other factors, such as the period until the expiry of option and the interest rate, are considered secondary [Alexander 2008a].

The basic types of dynamic hedging are delta hedging, delta-gamma hedging and delta-gamma-vega hedging. Delta hedging involves the use of the delta to determine the structure of the portfolio. This coefficient is a measure of the sensitivity of the option's value to changes in the price of the underlying instrument and is interpreted as the change in the value of the option per unit price change of the underlying instrument [Tarczyński 2003; Weron, Weron 2005; Jajuga, Jajuga 2006; Jajuga (ed.) 2009]. Since the delta for the call option assumes positive values from the range $(0 ; 1)$, and for the put option negative from the range $(-1 ; 0)$, to obtain the delta for the entire portfolio equal to zero, the appropriate positions within the options should be taken.

The delta for the entire portfolio can be determined as follows:

$$
\text { Delta }_{P}=n_{0}+n_{1} \text { Delta }=0,
$$

where: Delta $_{P}$ - means delta for the whole portfolio, $n_{0}$ - number of underlying instruments, $n_{1}$ - number of options, Delta - option delta coefficient. The underlying instrument's delta is equal to 1 .

As results from the presented equation, hedging the purchase position of the underlying instrument $\left(n_{0}>0\right)$ requires the adoption of sales position $\left(n_{1}<0\right)$ of the appropriate number of call options (Delta $>0)$ or purchase $\left(n_{1}>0\right)$ of the appropriate number of put options $($ Delta $<0)$. As option prices change to a lesser extent than the price of the underlying instrument, the number of option positions should be respectively higher [Alexander 2008a]. The adoption of appropriate proportions in the portfolio requires knowledge of the delta calculated for the given option.

Delta-gamma hedging consists in the construction of a portfolio of two options and an underlying instrument using the delta and gamma coefficients. The gamma is a measure of the sensitivity of delta to changes in the price of the underlying instrument and means a change of delta at a unit price change of the underlying instrument. 
This kind of portfolio will be delta neutral if:

$$
\text { Delta }_{P}=n_{0}+n_{1} \text { Delta }_{1}+n_{2} \text { Delta }_{2}=0,
$$

where: Delta $_{P}-$ means delta for the whole portfolio, $n_{1}$ - number of first options, Delta $a_{1}$ - delta of first option, $n_{2}$ - number of second options, Delta - delta of second option.

The portfolio will be gamma neutral if:

$$
\text { Gamma }_{P}=n_{1} \text { Gamma }_{1}+n_{2} \text { Gamma }_{2}=0,
$$

where: $G_{a m m a}$ - gamma for the entire portfolio, Gamma - gamma of the first option, Gamma $a_{2}$ gamma of the second option. Gamma for the underlying instrument is equal to zero [Jarrow, Turnbull 2000].

Fixing $n_{0}$ for the underlying instrument enables, with the knowledge of the delta and gamma coefficients of individual options, calculating from this system of equations $n_{1}$ and $n_{2}$, respectively.

In contrast, delta-gamma-vega hedging involves the simultaneous usage of three Greeks to build a portfolio consisting of three options and an underlying instrument. The delta and gamma are used to hedge the portfolio against changes in the price of the underlying instrument, and the vega coefficient to hedge against changes in the volatility of the underlying instrument. Vega is a measure of the sensitivity of the option value to changes of the price volatility of the underlying instrument, and its value means a change in the value of the option when the volatility changes by one percentage point.

The portfolio will be delta neutral if:

$$
\text { Delta }_{P}=n_{0}+n_{1} \text { Delta }_{1}+n_{2} \text { Delta }_{2}+n_{3} \text { Delta }_{3}=0,
$$

where: $n_{3}$ - number of third options, Delta $_{3}$ - third option delta, and the remaining designations as before.

The portfolio will be gamma neutral if:

$$
\text { Gamma }_{P}=n_{1} \text { Gamma }_{1}+n_{2} \text { Gamma }_{2}+n_{3} \text { Gamma }_{3}=0,
$$

where: Gamma $_{3}$ - the gamma of the third option, and the remaining designations as before.

The portfolio will be vega neutral if:

$$
V e g a_{P}=n_{1} V e g a_{1}+n_{2} V e g a_{2}+n_{3} V e g a_{3}=0,
$$

where: $V e g a_{1}$ - the vega of the first option, the $V e g a_{2}$ - the second option vega, $V e g a_{3}$ - the third option vega, and the remaining designations as before [Jarrow, Turnbull 2000]. Vega for the underlying instrument is equal to zero. 
In this case, as before, after determining $n_{0}$ and with the knowledge of the delta, gamma and vega coefficients of individual options, it is possible to calculate from the system of equations $n_{1}, n_{2}$ and $n_{3}$, respectively.

\section{Analysis of dynamic hedging effectiveness}

In the conducted empirical research, the adopted research method was the historical scenario method in which it was assumed that the market participant hedged the portfolio of shares corresponding to the WIG20 index in the entire analyzed period. At the beginning, the composition of the portfolio was specified, which was then modified at the end of each subsequent session, each time based on the calculated shares of the appropriately selected options. The call options on the WIG20 index with exercise prices closest to the current WIG20 index level and the forthcoming expiry dates were used for hedging.

In the case of delta hedging, the option with an exercise price closest to the WIG20 index level and with the closest expiration date was chosen each time. In the case of delta-gamma hedging, in addition to such an option, the option with the second nearest exercise price and with a longer expiry date of one month was chosen. On the other hand, for delta-gamma-vega hedging, the two options described above were used and in addition the option with the third closest exercise price and the closest expiration date.

The research covered the period from January 2, 2017 to December 27, 2018. In dynamic hedging, options on the WIG20 index listed throughout this period were applied. These were call options with different exercise prices adjusted to the WIG20 index levels and diversified expiry dates.

The delta, gamma and vega coefficients were used to determine the share of the index and the options selected each time in the portfolio. In this case, it was assumed at the beginning that the share of the WIG20 index (stock) in the portfolio does not change and amounts to 1 , while the share of options was determined in such a way that the delta, gamma and vega respectively calculated for the entire portfolio were equal to zero. This meant a neutral portfolio in regard to the delta, gamma and vega.

In the detailed calculations, data from the Warsaw Stock Exchange were used regarding the options prices and WIG20 index levels, as well as the delta, gamma and vega coefficients calculated by the Stock Exchange for individual options. Despite a two-year research period, a total of 341 observations were obtained due to frequently missing data regarding options, most likely resulting from the low liquidity of this market.

Greeks are determined in accordance with the Black-Scholes-Merton model based on the following formulas: 


$$
\begin{gathered}
\delta=e^{-y T} N\left(d_{1}\right), \\
\gamma=\frac{e^{-y T} N^{\prime}\left(d_{1}\right)}{S \sigma \sqrt{T}}, \\
v=e^{-y T} S N^{\prime}\left(d_{1}\right) \sqrt{T}, \\
d_{1}=\left[\ln (S / K)+\left(r-y+0,5 \sigma^{2}\right) T\right] /(\sigma \sqrt{T}),
\end{gathered}
$$

where: $S$ - current price of the underlying instrument, $K$ - exercise price of the option, $T$-period for the settlement (exercise) of option (in years), $r$ - risk-free interest rate (in annual terms), $y$ - dividend rate (in annual terms), $\sigma$ - volatility of the underlying instrument (standard deviation of the rate of return) (in annual terms), $N(\cdot)$ - distribution function for the standardized normal distribution, $N^{\prime}(\cdot)$ - density function of the standard normal distribution [Alexander 2008a].

The risk-free rate is estimated for each option expiration date separately through linear interpolation of available averages from WIBOR and WIBID for dates 1 week, 2 weeks, 1 month, 3 months, 6 months, 9 months. These rates are previously recalculated from annual capitalization to continuous capitalization. The volatility included in the model is the previously calculated implied volatility for a given option series resulting from the level of the option price. The dividend rate is calculated on each of the option expiration dates based on data on the value and payment dates of dividends set at the general shareholders' meeting this year or payout data for the previous year if the decision has not yet been made this year.

The effectiveness of the dynamic hedging used this way was determined based on the percentage changes of the value of the portfolio at the next session. In order to generalize the study results based on these changes, the arithmetic means, standard deviations and the smallest and largest values were calculated. The results of these calculations, together with the results on changes in the unhedged portfolio (WIG20 index), are presented in Table 1.

Table 1. Statistics of percentage changes of the value of specific portfolios

\begin{tabular}{|l|c|c|c|c|}
\hline \multirow{2}{*}{\multicolumn{1}{|c|}{ Portfolio }} & \multicolumn{4}{|c|}{ Chosen statistics } \\
\cline { 2 - 5 } & arithmetic mean & standard deviation & minimum & maximum \\
\hline Unhedged & $0.2374 \%$ & $0.9596 \%$ & $-2.7501 \%$ & $3.5543 \%$ \\
\hline Delta neutral & $0.0295 \%$ & $0.2356 \%$ & $-0.9930 \%$ & $0.6733 \%$ \\
\hline Delta-gamma-vega neutral & $-0.0432 \%$ & $0.3385 \%$ & $-2.1046 \%$ & $1.0432 \%$ \\
\hline
\end{tabular}

Source: own calculations.

It can be concluded from Table 1 that the effect of hedging is clearly visible for both delta hedging and delta-gamma-vega hedging. The average percentage changes in the value of hedged portfolios are definitely smaller, the standard deviations of the 
changes have also been significantly reduced, and the minimum and maximum values indicate a smaller spread of these changes. This indicates the effectiveness of delta hedging and delta-gamma-vega hedging used during the period considered. ${ }^{1}$ These values also indicate the higher effectiveness of delta hedging, where changes of the value of the portfolio oscillate closer to zero. The omitted initial results on delta-gamma hedging indicated that in this case hedging definitely did not fulfill its task. In order to facilitate the assessment of the effectiveness of delta and deltagamma-vega hedging, a VaR measure was applied in this regard. ${ }^{2}$

\section{Usage of historical VaR to compare the effectiveness of dynamic hedging}

Value at Risk (VaR) analysis using historical simulation based on data from previous research on both hedged and unhedged portfolios (WIG20 index) are presented in this section.

Historical VaR in value terms can be defined as the $\alpha$ quantile of the empirical income distribution. When calculating $\mathrm{VaR}$ in percentage terms based on one-day rates of return, the one-day VaR is the $\alpha$ quantile of the empirical distribution of these rates. In cases of a long period of historical observations, it is particularly important to correct historical returns so that they reflect current market conditions. This may in particular relate to the level of volatility of the analyzed instruments or the level of the risk-free rate. In the comparative analysis carried out, this aspect has not been taken into account, as it is about the comparison of the results from the entire researched periods, and not about the VaR estimation for the market situation at the end of a given period. The VaR compared was determined on a one day scale. If there was a need to rescale the VaR for a longer period, this can be done with a certain simplification using the square root formula, while for more accurate calculations the scaling exponent can be estimated which usually differs from 0.5 [Alexander 2008b].

For the $1 \% \mathrm{VaR}$ estimation, the sample size is considered to be at least 2,000 daily observations. As a result of the analysis, 341 observations were obtained, which means that VaR estimates should be treated with some caution. This measure was used mainly because of the ease of comparing the effectiveness of hedging.

For a relatively small research sample or calculation of extreme quantiles, the continuous distribution should be adjusted to the empirical distribution. In this case,

1 The effectiveness of dynamic hedging is confirmed by many research results, including: M. Avellaneda., A. Levy and A. Paras [1995], A. Gupta [1997], C. Alexander and L. Nogueira [2007], C. Alexander and A. Kaeck [2011].

2 The measures of hedging effectiveness based on a time series include: measures based on linear regression analysis - where the regression coefficient, constant and $\mathrm{R}^{2}$ determination coefficient are assessed, the variability-reduction measure, and the adjusted hedge interval test (more on this topic [Hailer, Rump 2005]). In particular, in this case the use of linear regression analysis deserves attention, although three amounts are assessed in this approach. 
the Johnson distribution was used, which is suitable when the returns are very skew or leptokurtic; $100 \alpha \% h$-day historical VaR based on the Johnson SU distribution is:

$$
V a R_{h, \alpha}=-\lambda \sinh \left(\frac{z_{\alpha}-\gamma}{\delta}\right)-\xi
$$

where the transformation parameters $\xi$-determines the location of the distribution, $\lambda$ - the scale, $\gamma$ - the skewness, $\delta$ - the kurtosis, sinh « is the hyperbolic sine function, and $z_{\alpha}$ - is the corresponding standard normal quantile: $z_{\alpha}=\Phi^{-1}(\alpha), \Phi-$ standard normal distribution function [Alexander 2008b].

In the analyzed case, due to the relatively small sample, the SU Johnson distribution was adopted to empirical distributions, using the algorithm suggested by $H$. Tuenter [2001] for the estimation of parameters. Based on the first four moments of returns from the portfolios, the parameters for the SU Johnson distributions were estimated, and then the corresponding VaR levels were calculated. The calculated statistics are given in Table 2, and the Johnson SU VaR estimates in Table 3.

Table 2. Johnson SU VaR statistics for estimating

\begin{tabular}{|l|c|c|c|}
\hline \multicolumn{1}{|c|}{ Statistics } & Unhedged portfolio & Delta neutral portfolio & $\begin{array}{c}\text { Delta-gamma-vega neutral } \\
\text { portfolio }\end{array}$ \\
\hline Mean & $0.2374 \%$ & $0.0295 \%$ & $-0.0432 \%$ \\
\hline Deviation & $0.9596 \%$ & $0.2356 \%$ & $0.3385 \%$ \\
\hline Skewness & 0.1921 & -1.0222 & -1.1513 \\
\hline Kurtosis & 0.3785 & 2.2440 & 5.8078 \\
\hline
\end{tabular}

Source: own calculations.

Table 3. Johnson SU VaR estimates

\begin{tabular}{|l|c|c|c|}
\hline Quantile & Unhedged portfolio & Delta neutral portfolio & $\begin{array}{c}\text { Delta-gamma-vega } \\
\text { neutral portfolio }\end{array}$ \\
\hline $1 \%$ & $1.93 \%$ & $0.69 \%$ & $1.11 \%$ \\
\hline $2 \%$ & $1.67 \%$ & $0.57 \%$ & $0.89 \%$ \\
\hline $3 \%$ & $1.50 \%$ & $0.49 \%$ & $0.77 \%$ \\
\hline $5 \%$ & $1.29 \%$ & $0.40 \%$ & $0.63 \%$ \\
\hline $10 \%$ & $0.95 \%$ & $0.28 \%$ & $0.44 \%$ \\
\hline
\end{tabular}

Source: own calculations.

Based on Table 3, it can be concluded that for each of the given quantiles, the risk of the unhedged portfolio is much higher than the risk of the hedged portfolios. The delta neutral portfolio has the lowest risk. In order to facilitate the comparison of delta and delta-gamma-vega hedging effectiveness after the estimation for selected $\mathrm{VaR}$ quantiles, the differences between VaR for hedged portfolios and VaR for the 
unhedged portfolio were calculated (see Table 4). This difference is a measure of the effectiveness of hedging and can be interpreted as the change in the level of risk resulting from the applied hedging method, expressed in percentage points.

Table 4. Differences in VaR levels for hedged and unhedged portfolios

\begin{tabular}{|l|l|c|}
\hline \multirow{2}{*}{ Quantile } & \multicolumn{2}{|c|}{ Hedging effect in percentage points } \\
\cline { 2 - 3 } & delta & delta-gamma-vega \\
\hline $1 \%$ & -1.24 & -0.82 \\
\hline $2 \%$ & -1.10 & -0.78 \\
\hline $3 \%$ & -1.01 & -0.73 \\
\hline $5 \%$ & -0.89 & -0.66 \\
\hline $10 \%$ & -0.67 & -0.51 \\
\hline
\end{tabular}

Source: own calculations.

Based on the results contained in Table 4, it can be concluded that for quantiles $1-10 \%$ the delta hedging effectiveness measured by VaR changes was from -0.67 to -1.24 percentage points. At lower quantiles the delta hedging effect increased. In this case, due to the relatively small test sample, VaR for the lower quantiles was not given.

For delta-gamma-vega hedging, this effectiveness for the given quantiles was from -0.51 to -0.82 percentage points. Therefore, there is no doubt that the use of delta hedging results in a greater reduction of portfolio risk. With a $1 \%$ quantile, the reduction is higher by 0.4 percentage point. It is worth emphasizing that the use of delta hedging involves the use of individual options, the use of delta-gamma-vega hedging requires the use of three respectively selected options every time. Taking into account transaction costs, delta hedging is therefore a much simpler solution and also less expensive.

In conclusion it can be said that among the delta, delta-gamma and delta-gammavega hedging analyzed, the most effective solution was delta hedging. Delta-gamma hedging did not reduce the risk of the portfolio at all, while delta-gamma-vega hedging reduced the portfolio risk to a lesser extent than delta hedging.

From a theoretical point of view, the more Greeks are used to determine the structure of the portfolio, the more effectively the portfolio should be hedged. Delta hedging should hedge against minor changes in the price of the underlying instrument (WIG20 index), delta-gamma hedging should also hedge against bigger changes in the price of the underlying instrument, while delta-gamma-vega hedging should additionally secure against changes in the volatility of the underlying instrument [Jarrow, Turnbull 2000]. However, the results of this research have not confirmed this. In the analyzed period, the use of delta hedging proved to be the most effective.

Comparing the obtained results to the results of this type of research carried out for the period from July 2007 to January 2008 [Węgrzyn 2013], it can be concluded 
that the conclusions are very similar. In those studies, significant effectiveness of delta hedging was found, which reduced the risk of the portfolio. Delta-gamma hedging did not bring the expected result and did not reduce the risk in relation to the unhedged portfolio. The use of delta-gamma-vega hedging in that case was also not effective and did not reduce the risk of the unhedged portfolio.

Thus, despite the long period of development of the Polish options market and the qualitative improvement in the relations of options' prices resulting from arbitrage, the effectiveness of delta-gamma and delta-gamma-vega hedging was not greater than delta hedging.

\section{Conclusion}

The conducted research confirmed that delta hedging using options is the most effective solution among the analyzed hedging types and also under current market conditions. In pursuing the purpose of the research, the effectiveness of individual types of dynamic hedging using the options on the WIG20 was determined and the results were compared with the results of previous research.

In this case, the qualitative changes on the options market that occurred from previous research did not significantly affect the effectiveness of delta-gamma or delta-gamma-vega hedging. The introduction of a new transaction system, the Universal Trading Platform, enabled the submission of investors' orders to be generated automatically, which probably contributed to reducing the scale of options price deviations from arbitrage relations, but the better market conditions for using the Black-Scholes-Merton options pricing model did not lead to an increase in the effectiveness of these types of hedging.

An important factor that could play a significant role here was that, along with qualitative changes on the Polish options market, no quantitative changes occurred in terms of turnover. The volume of trading on this market has been operating for many years at an increasingly lower level. After the collapse in 2012, this volume decreased, with the exception of 2013, for subsequent years until 2018. In 20172018, which is the research period, it reached a level close to that of 2005-2006. The relatively low liquidity is a factor that can cause various unusual price behaviour, and certainly makes it difficult to apply specific option strategies, especially those more complex requiring the use of a larger number of options. In addition, it is also a factor negatively affecting the size of spreads used by market makers.

As the situation on the Polish options market is changing quite dynamically, it should be noted that the results obtained could have been influenced by the research period used. The relatively short research period also did not allow the use of more advanced methods for measuring VaR. However, from a different perspective, the paper was about assessing the effectiveness of hedging in current market conditions, and the consideration of earlier years in the study could lead to an increase in the hedging effectiveness. 


\section{References}

Alexander C., 2008a, Market Risk Analysis. Pricing, Hedging and Trading Financial Instruments, J. Wiley, Chichester.

Alexander C., 2008b, Market Risk Analysis. Value-at-Risk Models, J. Wiley, Chichester.

Alexander C., Kaeck A., 2011, Does model fit matter for hedging? Evidence from FTSE 100 options, Journal of Futures Markets, vol. 32(7), pp. 609-638.

Alexander C., Nogueira L., 2007, Model-free hedge ratios and scale invariant models, Journal of Banking and Finance, vol. 31(6), pp. 1839-1861.

Avellaneda M., Levy A., Paras A., 1995, Pricing and hedging derivative securities in markets with uncertain volatilities, Applied Mathematical Finance, vol. 2, pp. 73-88.

Chance D.M., 2004, An Introduction to Derivatives \& Risk Management, South-Western, Mason.

Gupta A., 1997, On neutral ground, Risk, vol. 7, pp. 37-41.

Hailer A.C., Rump S.M., 2005, Evaluation of Hedge Effectiveness Tests, Journal of Derivatives Accounting, vol. 2(1), pp. 31-51.

Jajuga K. (ed.), 2009, Zarzadzanie ryzykiem, PWN, Warszawa.

Jajuga K., Jajuga T., 2006, Inwestycje. Instrumenty finansowe, aktywa niefinansowe, ryzyko finansowe, inżynieria finansowa, PWN, Warszawa.

Jarrow R., Turnbull S., 2000, Derivative Securities, South-Western College Publishing, Cincinnati.

Spremann K., 1991, Investition und Finanzierung, Oldenbourg, Wien.

Tarczyński W., 2003, Instrumenty pochodne na rynku kapitałowym, PWE, Warszawa.

Tuenter H., 2001, An algorithm to determine the parameters of SU curves in the Johnson system of probability distributions by moment matching, Journal of Statistical Computation and Simulation, vol. 70(4), pp. 325-347.

Węgrzyn R., 2010, Analiza operacji arbitrażowych w zakresie opcji na WIG20, Prace Naukowe Uniwersytetu Ekonomicznego we Wrocławiu, no. 117, pp. 450-460.

Węgrzyn R., 2011, Arbitrażowe ograniczenia i właściwości cen opcji. Analiza empiryczna, Zeszyty Naukowe Uniwersytetu Ekonomicznego w Krakowie, no. 864, pp. 115-128.

Węgrzyn R., 2013, Opcje jako instrumenty ograniczania ryzyka cen akcji. Problemy optymalizacji, Uniwersytet Ekonomiczny w Krakowie, Kraków.

Weron A., Weron R., 2005, Inżynieria finansowa, Wydawnictwa Naukowo-Techniczne, Warszawa. 